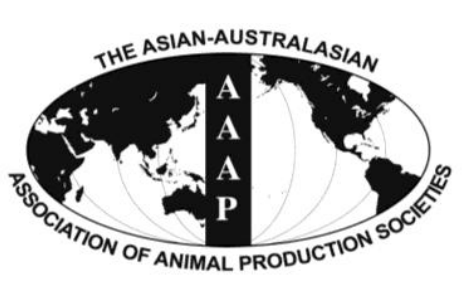

Open Access

\begin{tabular}{c} 
Open Access \\
Asian Australas. J. Anim. Sci. \\
Vol. 27, No. $4:$ 511-517 April 2014 \\
http://dx.doi.org/10.5713/ajas.2013.13617 \\
\hline www.ajas.info \\
pISSN 101 1-2367 elSSN 1976-5517
\end{tabular}

\title{
Effects of Microbial Additives on Chemical Composition and Fermentation Characteristics of Barley Silage
}

\author{
S. M. Amanullah ${ }^{1,2}$, D. H. Kim ${ }^{1}$, H. J. Lee ${ }^{1}$, Y. H. Joo ${ }^{1}$, S. B. Kim ${ }^{3}$, and S. C. Kim ${ }^{1}$ * \\ ${ }^{1}$ Division of Applied Life Science (BK21Plus, Institute of Agriculture and Life Science), \\ Gyeongsang National University, Jinju 660-701, Korea
}

\begin{abstract}
This study examined the effects of bacterial inoculants on chemical composition and fermentation indices of barley silage. Barley forage (Youngyang) was harvested at $24 \%$ dry matter (DM) and wilted to $47.9 \%$ DM. The wilted barley forage was chopped to 3-5 cm length and applied with no inoculant (CON), L. plantarum $\left(1 \times 10^{10} \mathrm{cfu} / \mathrm{g}\right.$, LP) or Effective Microorganisms $\left(0.5 \times 10^{9}\right.$ $\mathrm{cfu} / \mathrm{g}, \mathrm{EM})$. Then the forages were ensiled in four replications for each treatment in $20 \mathrm{~L}$ mini silos and stored for 100 days. The contents of crude protein and ether extract were higher in CON silage ensiled for 100-d, while the contents of DM and crude ash were higher in EM silage $(\mathrm{p}<0.05)$. The contents of ADF, NDF and hemicellulose as well as the in vitro DM digestibility were not affected by microbial inoculation $(\mathrm{p}>0.05)$. The $\mathrm{pH}$, ammonia-N concentration and lactate to acetate ratio were higher $(\mathrm{p}<0.05)$ in CON silage, while lactate concentrations were higher $(\mathrm{p}<0.05)$ in $\mathrm{CON}$ and LP silage. Acetate concentration and lactic acid bacteria was increased $(\mathrm{p}<0.05)$ by both inoculants (LP and EM), but propionate concentration and yeast was increased $(\mathrm{p}<0.05)$ by EM and LP, respectively. These results indicated that the fermentation quality of barley silage was improved by the application of bacterial inoculants. (Key Words: Aerobic Stability, Bacterial Inoculant, Barley Silage, Fermentation Indices)
\end{abstract}

\section{INTRODUCTION}

Ensiling is an important and most widely used tool for forage preservation occurred by fermentation under anaerobic condition by the naturally occurring epiphytic bacteria. These bacteria use the readily fermentable carbohydrates of plants to produce lactic acid which reduces the $\mathrm{pH}$ and thus preserves the nutrients and prevents the growth of undesirable microbes responsible for spoilage (McDonald et al., 1991). Usually, barley forage contains a high amount of water-soluble carbohydrates (McAllister et al., 1995; Hargreaves et al., 2009) providing ample substrate for the production of lactate needed to ensure

\footnotetext{
* Corresponding Author: S. C. Kim. Tel: +82-55-772-1947, Fax: +82-55-772-1949, E-mail: kimsc@gnu.ac.kr

${ }^{2}$ Bangladesh Livestock Research Institute, Savar, Dhaka-1314, Bangladesh.

${ }^{3}$ National Institute of Animal Science, RDA, Suwon 441-706, Korea.

Submitted Oct. 1, 2013; Accepted Nov. 29, 2013; Revised Dec. 19, 2013
}

preservation (Zahiroddin et al., 2004; Hargreaves et al., 2009). However, the speed and efficiency of fermentation depends largely on the type and number of lactic acid bacteria attached to crops.

Microbial inoculation, especially of homofermentative lactic acid bacteria (LAB) is a common practice to accelerate the fermentation resulting in good quality silage. The most common LAB used in silage inoculants is Lactobacillus plantarum (Muck, 2004; Sucu and Filya, 2006), which usually ferments 1 molecule of glucose into 2 molecules of lactic acid via the homofermentative EmbdenMeyerhof pathway. Previous findings suggest that $L$. plantarum based LAB inoculants can improve barley silage fermentation (Zahiruddini et al., 2004; Baah et al., 2011), and animal performance (McAllister et al., 1995, 1999), however, the lack of consistency was also reported (Muck, 1993).

The concept of effective microorganisms (EM) was developed by Higa (1991). The EM consists of mixed cultures of beneficial naturally occurring microorganisms, 
developed mainly as inoculants for increasing soil and plant microbial diversity. The EM contains selected species of microorganisms including predominant populations of LAB and yeasts as well as smaller numbers of photosynthetic bacteria, actinomycetes and other types of organisms (Higa, 1991). In South Korea, L. plantarum is the major bacterial inoculant used in the field and traditionally some farmers also use locally developed EM as silage inoculants. However, farmers reported variable results and yet the efficacy of local EM on forage ensiling is not much studied. Therefore, this study was conducted to know the efficacy of effective microorganisms (EM) as bacterial inoculants for whole crop barley silage compared to L. platarum.

\section{MATERIALS AND METHODS}

\section{Silage making}

Barley (Youngyang) was grown at Gyeongsang National University Research Farm, Jinju, South Korea and the forage harvested at $24 \% \mathrm{DM}$ with sickle and wilted for $24 \mathrm{~h}$. After wilting, the DM content of forage was attained to $47.9 \%$. The wilted barley forage was chopped to $3-5 \mathrm{~cm}$ length and divided in three parts for use in the following treatments: i) water $(2 \mathrm{~mL} / \mathrm{kg}$ of fresh forage), designated as control (CON); ii) L. plantarum $\left(1.5 \times 10^{7} \mathrm{cfu} / \mathrm{g}\right.$ of fresh forage; CMbio, South Korea), designated as LP; iii) effective microorganisms $\left(0.5 \times 10^{6} \mathrm{cfu} / \mathrm{g}\right.$ of fresh forage; Jinju Agricultural Station, South Korea), designated as EM. After application of bacterial inoculants, the forages from each treatment were sub-sampled in quadruplicate and stored at $-20^{\circ} \mathrm{C}$ for the analysis of nutrient content. Then the forage $(3 \mathrm{~kg})$ was ensiled into mini bucket silos $(10 \mathrm{~L}$ capacity) in quadruplicate for 100 days (Ranjit and Kung, 2000). At silo opening after 100 days of ensiling, silages were sub-sampled for the analyses of nutrient contents, fermentation indices and aerobic stability.

\section{Making silage extract}

Silage extract was prepared by macerating $20 \mathrm{~g}$ of fresh silage with $200 \mathrm{~mL}$ of sterile ultra pure water in a laboratory blender for $30 \mathrm{~s}$, and then, filtered through 2 layers cheesecloth. A part of the fresh extract was used to determine $\mathrm{pH}$ and the counts of $\mathrm{LAB}$, yeast and mold at the day of silo opening and the rest was stored at $-20^{\circ} \mathrm{C}$ for ammonia-N, lactic acid and other volatile fatty acids (VFA) analysis and extraction of microbial DNA.

\section{Laboratory analysis}

Fresh barley forage and silage (10 g) were oven-dried at $105^{\circ} \mathrm{C}$ for $24 \mathrm{~h}$ to determine DM (OF-22GW, JEIO TECH, Korea). About $500 \mathrm{~g}$ of forage and silage were dried separately at $60^{\circ} \mathrm{C}$ for $48 \mathrm{~h}$ and ground by a Wiley mill with
$1 \mathrm{~mm}$ screen to use for chemical analysis. Standard Kjeldahl procedure and Soxhlet method (AOAC, 1995) were used to determine the $\mathrm{CP}$ and ether extract (EE) contents, respectively. Crude ash concentration was determined with a muffle furnace at $550^{\circ} \mathrm{C}$ for $5 \mathrm{~h}$. The contents of NDF and ADF were determined by using Ankom200 fiber analyzer (Ankom Technology, Macedon, NY) following the method of Van Soest et al. (1991). Hemicellulose concentration was calculated by the difference between NDF and ADF. The IVDMD was determined following the method described by Tilley and Terry (1963) using ANKOM ${ }^{I I}$ Daisy Incubator (ANKOM Technology, Macedon, NY, USA). The $\mathrm{pH}$ and ammonia-N concentration were measured by a $\mathrm{pH}$ meter (SevenEasy, Mettler Toledo, Switzerland) and colorimetry (Chaney and Marbach, 1962), respectively. For lactate and VFA analysis, silage extract was centrifuged at $5,645 \times g$ for $15 \mathrm{~min}$, and then, the supernatant was collected. Concentrations of lactate and VFA was measured in a HPLC (L-2200, Hitachi, Tokyo, Japan) fitted with a UV detector (L-2400, Hitachi, Tokyo, Japan) and a column (Metacarb 87H, Varian, CA, USA) described by Adesogan et al. (2004).

\section{Microbial enumeration}

The counts of LAB, yeast and mold were conducted from silage extract, considered as the first dilution. Ten fold serial dilutions of the suspension were prepared and $100 \mu \mathrm{L}$ aliquots of three consecutive dilutions $\left(10^{-5}\right.$ to $\left.10^{-7}\right)$ were plated in triplicate onto a selective agar medium. The lactobacilli MRS agar media (MRS; Difco, Detroit, MI, USA) for the isolation and enumeration of $\mathrm{LAB}$, and potato dextrose agar (PDA; Difco, Detroit, MI, USA) for the isolation and enumeration of yeasts and molds were used, respectively. Lactobacilli MRS agar plates were placed in a $\mathrm{CO}_{2}$ incubator (Thermo Scientific, USA) at $39^{\circ} \mathrm{C}$ for $24 \mathrm{~h}$ and PDA plates were incubated at $39^{\circ} \mathrm{C}$ for $24 \mathrm{~h}$ in normal incubator (Johnsam Corporation, Korea). Visible colonies were counted from the plates at appropriate dilutions and the number of colony forming units (CFU) was expressed per gram of silage.

\section{Aerobic stability}

The silage $(1 \mathrm{~kg})$ from each silo was transferred to open-top polyethylene bags to determine the aerobic stability. Thermocouple wire was placed to the center of the silage and connected to a data logger (MORGAN, TR$60 \mathrm{CH}$, Korea) along with a computer that recorded the temperature at every $30 \mathrm{~min}$. Aerobic stability was determined by the time that elapsed before a $2^{\circ} \mathrm{C}$ increase in silage temperature above the ambient temperature as suggested by Arriola et al. (2011). 


\section{DNA extraction, primer and PCR condition}

The DNA of $L$. plantarum was extracted by using QIAamp DNA mini kit (Qiagen, USA) following the manufacturer's protocol. The DNA concentrations were measured by using a NanoDrop Spectrophotometer (ND1000, USA). Amplification of DNA was performed using Bio-Rad C1000 Touch Thermal cycler real-time PCR detection system (CFX96 Real-Time system, Bio-Rad Laboratories, Inc., Hercules, CA, USA). Amplification conditions consisted of an initial denaturation step of $94^{\circ} \mathrm{C}$ for $120 \mathrm{~s}$, followed by 35 cycles of: $94^{\circ} \mathrm{C}$ for $20 \mathrm{~s}, 52^{\circ} \mathrm{C} 20$ $\mathrm{s}$, and $72^{\circ} \mathrm{C}$ for $20 \mathrm{~s}$; a final elongation step of $72^{\circ} \mathrm{C}$ for 5 min. Reaction was performed in $25 \mu \mathrm{L}$ amplification mixtures with $2.5 \mu \mathrm{L}$ of $10 \times$ buffer, $2 \mu \mathrm{L}$ of dNTP, $1.5 \mu \mathrm{L}$ of forward primer (5'-TCAAATGGCAAATGAACAGC-3'), $1.5 \mu \mathrm{L}$ of reverse primer (5'-GGACATGGATGTACC CAACC-3'), $1 \mathrm{U}$ of taq polymerase (Genetbio, Korea), $1 \mu \mathrm{L}$ of DNA, and $16.3 \mu \mathrm{L}$ of distilled water. The amplified fragments were subjected to electrophoresis on $1.5 \%$ agarose gel and visualized after stained with ethidium bromide under UV illumination.

\section{Statistical analysis}

The data were analyzed using GLM procedure of SAS (2002). Mean separation was performed by Tukey's test. And the significant differences were declared at $p<0.05$.

\section{RESULTS}

The chemical composition of barley forage before ensiling (after $24 \mathrm{~h}$ of wilting) is shown in Table 1. The DM, $\mathrm{CP}$ and NDF contents of barley forage were $47.9 \%, 7.23 \%$, and $57.4 \%$, respectively.

Table 2 shows the chemical composition and IVDMD of barley silage ensiled for 100 days. The contents of DM was observed higher in EM silage $(\mathrm{p}<0.05)$, where $\mathrm{CP}$ and $\mathrm{EE}$ contents were higher in CON silage than in other silages $(\mathrm{p}<0.05)$. The NDF, ADF, hemicelluloses and IVDMD were not affected by bacterial inoculation ( $p>0.05)$.

The fermentation indices of barley silage ensiled for 100 days are shown in Table 3 . The lowest $\mathrm{pH}$ was observed in

Table 1. Chemical composition of barley forage (Youngyang) before ensiling $(\%, \mathrm{DM})$

\begin{tabular}{lc}
\hline & Barley forage \\
\hline Dry matter & 47.9 \\
Crude protein & 7.23 \\
Ether extract & 2.32 \\
Crude ash & 8.21 \\
Neutral detergent fiber & 57.4 \\
Acid detergent fiber & 34.8 \\
Hemicellulose & 22.6 \\
\hline
\end{tabular}

Table 2. Effects of microbial additives on chemical composition and in vitro dry matter digestibility of barley silage (Youngyang) ensiled for $100 \mathrm{~d}(\%, \mathrm{DM})$

\begin{tabular}{lcccc}
\hline \multirow{2}{*}{ Item } & \multicolumn{3}{c}{ Treatment $^{\mathrm{1}}$} & \multirow{2}{*}{ SEM } \\
\cline { 2 - 4 } & CON & LP & EM & \\
\hline Dry matter & $43.1^{\mathrm{b}}$ & $43.5^{\mathrm{b}}$ & $46.2^{\mathrm{a}}$ & 0.694 \\
Crude protein & $8.72^{\mathrm{a}}$ & $8.28^{\mathrm{b}}$ & $8.03^{\mathrm{b}}$ & 0.185 \\
Ether extract & $4.08^{\mathrm{a}}$ & $3.04^{\mathrm{b}}$ & $3.18^{\mathrm{b}}$ & 0.137 \\
Crude ash & $7.70^{\mathrm{b}}$ & $7.94^{\mathrm{b}}$ & $8.43^{\mathrm{a}}$ & 0.105 \\
Neutral detergent fiber & 57.3 & 57.5 & 58.9 & 1.675 \\
Acid detergent fiber & 35.6 & 37.2 & 37.7 & 1.435 \\
Hemicellulose & 21.7 & 20.3 & 21.2 & 0.546 \\
In vitro dry matter & 41.4 & 41.7 & 40.0 & 1.797
\end{tabular}

digestibility

${ }^{1} \mathrm{CON}=$ No additive; LP $=L$. plantarum $\left(2 \times 10^{10} \mathrm{cfu} / \mathrm{g}\right)$ with barley forage; $\mathrm{EM}=$ Effective microorganisms $\left(0.5 \times 10^{9} \mathrm{cfu} / \mathrm{g}\right)$ with barley forage.

${ }^{a, b}$ Means in the same row with different superscripts differ significantly $(\mathrm{p}<0.05)$.

LP silage (4.57) followed by EM (4.72) and CON (5.15) $(\mathrm{p}<0.05)$. Concentration of ammonia- $\mathrm{N}$ was highest in the CON silage $(p<0.05)$, but no difference was observed between LP and EM silage ( $p>0.05)$. Lactate concentrations in LP and CON silage were higher than that in EM silage, whereas acetate concentration was higher in EM and LP silages than in CON silage $(\mathrm{p}<0.05)$. The EM silage also had the highest propionate and butyrate concentration after $100 \mathrm{~d}$ of ensiling $(\mathrm{p}<0.05)$. Lactate to acetate ratio was observed highest in the CON silage, followed by LP and EM silage $(\mathrm{p}<0.05)$.

The aerobic stability and microbial counts of barley silage ensiled for 100 days are shown in Table 4. Yeast count was lower in EM silage than in LP, and lactic acid bacteria was observed higher in LP and EM silages than in the CON silage $(p<0.05)$. However, there was no difference $(p>0.05)$ in aerobic stability and mold count among the

Table 3. Effect of microbial additives on fermentation characteristics of barley silage (Youngyang) ensiled for $100 \mathrm{~d}$ (\% of DM or as stated)

\begin{tabular}{|c|c|c|c|c|}
\hline \multirow{2}{*}{ Item } & \multicolumn{3}{|c|}{ Treatment $^{1}$} & \multirow{2}{*}{ SEM } \\
\hline & $\mathrm{CON}$ & LP & EM & \\
\hline $\mathrm{pH}$ & $5.15^{\mathrm{a}}$ & $4.57^{c}$ & $4.72^{\mathrm{b}}$ & 0.038 \\
\hline Ammonia-N (\%) & $0.090^{\mathrm{a}}$ & $0.072^{\mathrm{b}}$ & $0.072^{\mathrm{b}}$ & 0.004 \\
\hline Lactate $(\%)$ & $0.93^{\mathrm{a}}$ & $1.15^{\mathrm{a}}$ & $0.20^{\mathrm{b}}$ & 0.168 \\
\hline Acetate $(\%)$ & $0.48^{\mathrm{b}}$ & $1.04^{\mathrm{a}}$ & $0.92^{\mathrm{a}}$ & 0.124 \\
\hline Propionate (\%) & $0.12^{\mathrm{b}}$ & $0.11^{\mathrm{b}}$ & $0.64^{\mathrm{a}}$ & 0.025 \\
\hline Buytrate (\%) & $0.19^{\mathrm{ab}}$ & $0.16^{\mathrm{b}}$ & $0.22^{\mathrm{a}}$ & 0.017 \\
\hline Lactate/acetate ratio & $1.94^{\mathrm{a}}$ & $1.11^{\mathrm{b}}$ & $0.22^{\mathrm{c}}$ & 0.171 \\
\hline \multicolumn{5}{|c|}{$\begin{array}{l}{ }^{1} \mathrm{CON}=\mathrm{No} \text { additive; } \mathrm{LP}=L \text {. plantarum }\left(2 \times 10^{10} \mathrm{cfu} / \mathrm{g}\right) \text { with barley } \\
\text { forage; } \mathrm{EM}=\text { Effective microorganisms }\left(0.5 \times 10^{9} \mathrm{cfu} / \mathrm{g}\right) \text { with barley } \\
\text { forage. }\end{array}$} \\
\hline
\end{tabular}


Table 4. Effect of microbial additives on aerobic stability and microbial counts of barley silage (Youngyang) ensiled for $100 \mathrm{~d}$

\begin{tabular}{|c|c|c|c|c|}
\hline & & eatmen & & SFM \\
\hline & $\mathrm{CON}$ & LP & EM & SE \\
\hline Aerobic stability (h) & 75.7 & 76.4 & 76.0 & 0.955 \\
\hline Yeast $(\log 10 \mathrm{cfu} / \mathrm{g})$ & $5.43^{\mathrm{ab}}$ & $5.73^{\mathrm{a}}$ & $5.23^{\mathrm{b}}$ & 0.163 \\
\hline Mold $(\log 10 \mathrm{cfu} / \mathrm{g})$ & 5.20 & 5.05 & 4.48 & 0.309 \\
\hline $\begin{array}{l}\text { Lactic acid bacteria } \\
(\log 10 \mathrm{cfu} / \mathrm{g})\end{array}$ & $3.52^{\mathrm{b}}$ & $4.13^{\mathrm{a}}$ & $4.10^{\mathrm{a}}$ & 0.122 \\
\hline $\begin{array}{l}{ }^{1} \mathrm{CON}=\mathrm{No} \text { additive } \\
\text { forage; EM = Effect } \\
\text { forage. } \\
{ }^{\mathrm{a}-\mathrm{c}} \text { Means in the same }\end{array}$ & $L_{0}$ & $\begin{array}{l}m(2 x \\
(0.5 x\end{array}$ & $\mathrm{fu} / \mathrm{g})$ & ar \\
\hline
\end{tabular}

silages.

The gel electrophoresis analysis after PCR amplification of $L$. plantarum DNA in silages is shown in Figure 1. It was observed that $L$. plantarum DNA was only present in LP silage.

\section{DISCUSSION}

The chemical composition of barley forage before ensiling is characterized by higher DM, lower CP and EE but higher NDF content in this study compared to our previous study (unpublished) and Park et al. (2008) with the same barley variety, or Zahiruddini et al. (2006) with other barley forage. The NDF content was lower than reported by Tudisco et al. (2009, 2010). The daylong (24 h) wilting of forages may have resulted in a higher DM content compared to other studies. Further, chemical composition of forages may be affected by the varietal difference, soil conditions, dose of fertilization, maturity at harvest etc (Adesogan et al., 2002).

The increased DM content in EM silage indicated good fermentation and preservation of nutrients in this silage. There was no difference in DM content between CON and LP inoculated silages in this study. Silage DM content was not affected by bacterial inoculation (Zahiroddini et al., 2004, 2006; Baah et al., 2011). Elevated ash content in silage is usually considered a result of soil contamination
(Seglar, 2003). However, apparently there was no soil contamination observed in any of the silages in this study. The significantly higher ash content in EM silage thus might have originated from the proportional changes in other nutrients.

The proteolysis of forage is usually caused microbes during silage fermentations which can increase ammonia-N concentration in silage (Oshima and McDonald, 1978). The result of higher $\mathrm{CP}$ content in CON silage compared to inoculated silages (LP and EM) in this study seems unusual considering the silage fermentation indices obtained in the study. Both the inoculated silages had significantly lower terminal $\mathrm{pH}$ and ammonia-N concentrations than that in the CON silage (Table 3). It is expected that protein of inoculated silages would better preserved than in CON silage. However, this unexpected result could be explained partially by an increase of the LAB count in LP and EM silages compared to CON silage. Some LAB species can take up the ammonia-N released from amino acid catabolism for their cellular growth (McDonald et al., 1991). Taylor et al. (2002) also reported a reduction in CP in whole crop barley silage inoculated with $L$. buchneri $\left(5 \times 10^{5} \mathrm{cfu} / \mathrm{g}\right.$ of forage) along with an enzyme. Fatty acids (FA) in silages are sometimes subjected to decomposition by bacterial inoculation, as we observed decreased ether extract content in both the LP and EM silages. Warren et al. (2002) found that use of bacterial inoculants decreased total FA concentrations in perennial ryegrass and red clover (Trifolium pratense L.) silages. Boufaïed et al. (2003) reported that use of a bacterial inoculant resulted in a decline in the total FA content in grass silage and haylage made from timothy. The lack of effect of bacterial inoculation on ADF and NDF content of silage in this study was in agreement with other previous studies (Ranjit and Kung, 2000; Kung and Ranjit, 2001).

The addition of homofermentative LAB inoculant usually ensures rapid and vigorous fermentation resulting in faster accumulation of lactate, lower $\mathrm{pH}$ values and improved forage conservation (Muck, 1993; Henderson, 2003). In this study, both the inoculated silages (LP and EM) had significantly lower $\mathrm{pH}$ than the control $(\mathrm{CON})$

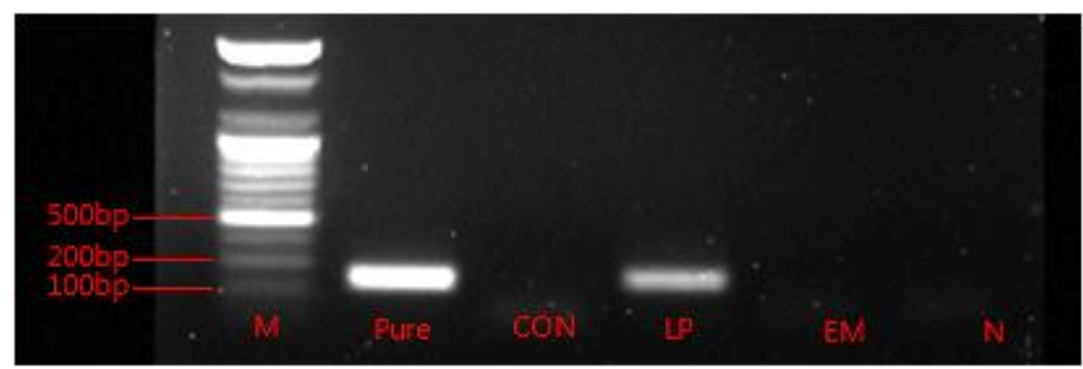

Figure 1. Gel electrophoresis analysis after PCR amplification of $L$. plantarum DNA in different silages. Lanes: M, DNA ladder/marker; Pure, pure culture of L. plantarum; CON, untreated control; LP, silage treated with L. plantarum; EM, silage treated with effective microorganism (EM); N, negative control. 
which could be attributed to better fermentation by LP and EM inoculation. The good silage fermentation is further confirmed by higher lactate concentration in LP, but unexpectedly not in EM silage. Even with a significantly lower $\mathrm{pH}$ than the CON silage, the EM silage had about five fold lower lactate content than the CON silage. However, this silage (EM) contained more than double acetate and fivefold higher propionate concentration compared to CON silage. Though lactate has the major role in lowering $\mathrm{pH}$ in silage (Shaver, 2003; Zahiruddini et al., 2004), other organic acids are also responsible for the $\mathrm{pH}$ drop in silage (Jalč et al., 2009). Not only were there lower ammonia-N concentrations in LP and EM silage compared to $\mathrm{CON}$ silage, but they also had higher organic acid (lactate+VFA) concentrations (2.46\% and $1.98 \%$ vs $1.72 \%$ ) which could explain the lower $\mathrm{pH}$ in the bacterial inoculants (LP and EM) in this study. The higher ammonia-N content in the control silage was due to protein decomposition resulting from the higher $\mathrm{pH}$ in this silage. The higher $\mathrm{pH}$ indicates poor fermentation and is responsible for protein loss in silage (Muck, 1993).

The higher concentration of acetate, propionate and butyrate in EM silage may be due to the multi species microbial composition of EM. There may be some microbes in EM responsible for the production of these acids or some species (e.g. Lactobacillus buchneri) were present that are capable of converting lactic acid to acetic acid in anaerobic conditions (Oude Elferink et al., 2001). The highest acetic acid content in LP silage in this study is little surprising. Usually, L. plantarum ferments 1 molecule of glucose into 2 molecules of lactic acid via the homofermentative EmbdenMeyerhof pathway, and thus $L$. plantarum inoculated silages contained abundant lactate and lower acetate concentration (Muck, 1993). However, L. plantarum can ferment pentoses into lactic acid, carbon dioxide, and acetic acid via the less efficient heterofermentative pathway when glucose is lacking (Holzer et al., 2003), but we did not have an analysis to ensure the lack of glucose in the forages in this study. The highest butyrate concentration in EM silage should not be confused with clostridial fermentation. Silage that contained more than $0.5 \%$ (\% of DM) of butyric acid may consider as clostridial silage (Kung and Shaver, 2001), but in this study its concentration was much lower than this suggested level. Lower lactate and higher acetate content in EM silage further gave a lower lactate/acetate ratio. High lactate to acetate ratio in silage is usually considered as an indicator of good fermentation (Jalč et al., 2009), but in this study, lower lactate/acetate ratio did not affect silage quality in EM silage.

The higher LAB count in LP and EM silage than in the control was directly due to the bacterial inoculation. Nevertheless, the presence of the species $L$. plantarum was confirmed only in the LP silage by PCR analysis followed by gel electrophoresis (Figure 1). Therefore, the fermentation in CON and EM silage was largely by the other LAB species other than L. plantarum. The EM silage had a decreased yeast and mold count, either statistically or numerically, compared with the other silages. Higher concentration of acetate and propionate were the underlying reasons for lowering yeast and mold in this silage. Courtin and Spoelstra (1990) and Weissbach (1996) identified that the amount of undissociated acetate is the most important inhibitory factor of yeast growth in naturally fermented silages. Propionate has also been shown to exhibit antifungal activity (Weinberg et al., 1995; Higginbotham et al., 1998). The LP silage also has high acetate content but no inhibitory effect on yeast and mold was observed in this silage. In both the silages (LP and EM) the above results did not reflected in improving aerobic stability of silage, which remained unaffected by the inoculation of microbes in this study.

Generally, barley forage has abundant fermentable carbohydrates and a low buffering capacity (Acosta et al., 1991). Together with the above characteristics of barley, uniform packing and high degree of oxygen exclusion that can be obtained in mini-silos sometimes offset or marginally reduces the benefits of microbial inoculation (Zahiroddini et al., 2006). Despite this, the results of microbial enumeration and PCR study in this study suggested that the inoculated bacteria were sufficiently established during ensiling. As a result better fermentation was achieved in LP and EM inoculated silages as indicated by decreased $\mathrm{pH}$ and ammonia- $\mathrm{N}$ compared to the control. However, further research is needed to ensure the efficacy of EM as a silage inoculant.

\section{ACKNOWLEDGEMENT}

This work was carried out with the support of "Cooperative Research Program for Agriculture Science and Technology Development (Project No. PJ0097752013)" Rural Development Administration, Republic of Korea. And, the authors (D. H. Kim, H. J. Lee, and Y. H. Joo) were supported by a scholarship from the BK21Plus Program, the Ministry of Education, Republic of Korea.

\section{REFERENCES}

Acosta, Y. M., C. C. Stalings, C. E. Polan, and C. N. Miller. 1991. Evaluation of barley silage harvested at boot and soft dough stages. J. Dairy Sci. 74:167-176.

Adesogan, A. T., N. K. Krueger, M. B. Salawu, D. B. Dean, and C. R. Staples. 2004. The influence of treatment with dual-purpose bacterial inoculants or soluble carbohydrates on the fermentation and aerobic stability of bermuda grass. J. Dairy Sci. 87:3407-3416.

Adesogan, A. T., L. E. Sollenberger, Y. C. Newman, and J. M. B. 
Vendramini. 2002. Factors affecting forage quality. In: Florida Forage Handbook, Department of Agronomy, University of Florida, Gainesville, FL 32611.

Arriola, K. G., S. C. Kim, C. R. Staples, and A. T. Adesogan. 2011. Effect of applying inoculants containing different types of bacteria to corn silage on the performance of dairy cattle. J. Dairy Sci. 94:3973-3979.

AOAC. 1995. Official methods of analysis. 15th edn, Association of Official Analytical Chemists, Arlington, VA, USA.

Baah, J., W. Addah, E. K. Okine, and T. A. McAllister. 2011. Effects of homolactic bacterial inoculant alone or combined with an anionic surfactant on fermentation, aerobic stability and in situ ruminal degradability of barley silage. Asian-Aust. J. Anim. Sci. 24:369-378.

Boufaïed, H., P. Y. Chouinard, G. F. Tremblay, H. V. Petit, R. Michaud, and G. Bélanger. 2003. Fatty acids in forages. I. Factors affecting concentrations. Can. J. Anim. Sci. 83:501511.

Chaney, A. L. and E. P. Marbach. 1962. Modified reagents for determination of urea and ammonia. Clin. Chem. 8:130-132.

Courtin, M. G. and S. F. Spoelstra. 1990. A simulation model of the microbiological and chemical changes accompanying the initial stage of aerobic deterioration of silage. Grass Forage Sci. 45:153-165.

Hargreaves, A., J. Hill, and J. D. Leaver. 2009. Effect of stage of growth on the chemical composition, nutritive value and ensilability of whole-crop barley. Anim. Feed Sci. Technol. 152:50-61.

Henderson, N. 1993. Silage additives. Anim. Feed Sci. Technol. 45:35-56.

Higa, T. 1991. Effective microorganisms: A biotechnology for mankind. Proceedings of the First International Conference on Kyusei Nature Farming. U.S. Department of Agriculture, Washington, DC, USA. pp. 8-14.

Higginbotham, G. E., S. C. Mueller, K. K. Bolsen, and E. J. DePeters. 1998. Effects of inoculants containing propionic acid bacteria on fermentation and aerobic stability of corn silage. J. Dairy Sci. 81:2185-2192.

Holzer, M., E. Mayrhuber, H. Danner, and R. Braun. 2003. The role of Lactobacillus buchneri in forage preservation. Trends Biotechnol. 21:282-287.

Jalč, D., A. Lauková, M. Simonová, Z. Váradyová, and P. Homolka. 2009. The use of bacterial inoculants for grass silage: their effects on nutrient composition and fermentation parameters in grass silages. Czech J. Anim. Sci. 54:84-91.

Kung, L. Jr. and R. Shaver. 2001. Interpretation and use of silage fermentation analysis reports. In: Focus on Forage, University of Wisconsin Extension, USA, 3(13):1-5.

Kung, L. Jr. and N. K. Ranjit. 2001. The effect of Lactobacillus buchneri and other additives on the fermentation and aerobic stability of barley silage. J. Dairy Sci. 84:1149-1155.

McAllister, T. A., G. D. Inglis, Z. Mir, and A. N. Hristov. 1999. Effect of inoculants on fermentation and performance of feedlot cattle fed barley and corn silage. Final Report, Project A00825-939, Agriculture and Agri-Food Canada Research Centre/Pioneer Hi-Bred International, Marlborough, Wiltshire, UK

McAllister, T. A., L. B. Selinger, L. R. McMahon, H. D. Bae, T. J. Lysyk, S. J. Oosting, and K. J. Cheng. 1995. Intake, digestibility and aerobic stability of barley silage inoculated with mixtures of Lactobacillus plantarum and Enterococcus faecium. Can. J. Anim. Sci. 75:425-432.

Muck, R. E. 1993. The role of silage additives in making high quality silage. Proceedings of the National Silage Production Conference on Silage Production from Seed to Animal, Syracuse, NY, USA. pp. 106-116.

Muck, R. E. 2004. Effects of corn silage inoculants on aerobic stability. Trans. ASAE. 47:1011-1016.

Ohshima, M. and P. McDonald. 1978. A review of the changes in nitrogenous compounds of herbage during ensilage. J. Sci. Food Agric. 29:497-505.

Oude Elferink, S. J. W. H., J. Krooneman, J. C. Gottschal, S. F. Spoelstra, F. Faber, and F. Driehuis. 2001. Anaerobic conversion of lactic acid to acetic acid and 1,2-propanediol by Lactobacillus buchneri. Appl. Environ. Microb. 67:125-132.

Park, T. I., O. K. Han, J. H. Seo, J. S. Choi, K. H. Park, and J. G. Kim. 2008. New barley cultivars with improved morphological characteristics for whole crop forage in Korea. J. Korean. Grass. Forage Sci. 28:193-202.

Ranjit, N. K. and L. Jr. Kung. 2000. The effect of Lactobacillus buchneri, Lactobacillus plantarum, or a chemical preservative on the fermentation and aerobic stability of corn silage. J. Dairy Sci. 83:526-535.

Seglar, B. 2003. Fermentation analysis and silage quality testing. Proceedings of the Minnesota Dairy Health Conference. College of Veterinary Medicine, University of Minnesota, May 2003.

Shaver, R. D. 2003. Practical application of new forage quality tests. Proceedings of the 6th Western Dairy Management Conference, Reno, USA. pp. 22-25.

SAS Institute Inc. 2002. SAS/STAT user's guide: Version 9. SAS Institute Inc., Cary, NC.

Sucu, E. and I. Filya. 2006. Effects of bacterial inoculants on fermentation, aerobic stability and rumen degradability characteristics of wheat silages. Turkish J. Vet. Anim. Sci. 30:187-193.

Taylor, C. C., N. J. Ranjit, J. A. Mills, J. M. Neylon, and L. Jr. Kung. 2002. The effect of treating whole-plant barley with Lactobacillus buchneri 40788 on silage fermentation, aerobic stability, and nutritive value for dairy cows. J. Dairy Sci. 85:1793-1800.

Tilley, J. M. A. and R. A. Terry. 1963. A two-stage technique for the in vitro digestion of forage crops. J. Br. Grassland Soc. 18:104-111.

Tudisco, R., S. Calabrò, M. Grossi, G. Piccolo, A. Guglielmelli, M. I. Cutrignelli, C. Caiazzo, and F. Infascelli. 2010. Influence of replacing corn silage with barley silage in the diets of buffalo cows on milk yield and quality. Vet. Res. Commun. 34 (Suppl. 1):S193-S196.

Tudisco, R., S. Calabrò, V. Terzi, V. Piccolo, A. Guglielmelli, and F. Infascelli. 2009. In vitro fermentation of ten cultivars of barley silage. Italian J. Anim. Sci. 8 (Suppl. 2):343-345.

Van Soest, P. J., J. B. Robertson, and B. A. Lewis. 1991. Methods for dietary fiber, neutral detergent fiber and non-starch polysaccharides in relation to animal nutrition. J. Dairy Sci. 74:3583-3597.

Warren, H. E., J. K. S. Tweed, S. J. Youell, R. J. Dewhurst, M. R. F. Lee, and N. D. Scollan. 2002. Effect of ensiling on the fatty 
acid composition of the resultant silage. In: Multi-Function Grasslands, 7. Grassland Science in Europe, (Ed. J. L. Durand, J. C. Emile, C. Huyghe, and G. Lemaire), 100-101.

Weinberg, Z. G., G. Ashbell, K. K. Bolson, G. Pahlow, Y. Hen, and A. Azrieli. 1995. The effect of a propionic acid bacterial inoculant applied at ensiling, with or without lactic acid bacteria, on the aerobic stability of pearl millet and maize silages. J. Appl. Bacteriol. 78:430-436.

Weissbach, F. 1996. New developments in crop conservation. Proceedings of the 11th International Silage Conference, Aberystwyth, IGER. pp. 11-25.
Zahiroddini, H., J. Baah, W. Absalom, and T. A. McAllister. 2004. Effect of an inoculant and hydrolytic enzymes on fermentation and nutritive value of whole crop barley silage. Anim. Feed Sci. Technol. 117:317-330.

Zahiroddini, H., J. Baah and T. A. McAllister. 2006. Effects of microbial inoculants on the fermentation, nutrient retention, and aerobic stability of barley silage. Asian-Aust. J. Anim. Sci. 19:1429-1436. 